\title{
Ben Jonson's Eloquent Nonsense: The Noisy Ordeals of Heard Meanings on the Jacobean Stage (1609-14)
}

\begin{abstract}
Ben Jonson's avid staging of noise, aural loss, and inadequate heard meanings in Epicene (1609) and Bartholomew Fair (1614) transforms the plays into peculiar venues for studying and negotiating early modern histories and theories of auditory reception. The ordeals of hearing in each play further betray deeper concerns with the increasingly alienating nature of voiced forms of communication in Jonson's overpopulated urban setting. This study uncovers local histories of aural failure which indicate that the plays were meant to be heard and in so doing question the very nature of hearing both in the crowded playhouses and within the extended topographic perimeter of Jacobean London.
\end{abstract}

An enthusiastic lover of learning, erudition, and the humanist ideal of imitating the classics, Ben Jonson is surpassed only by John Milton as the most learned of all early modern poets. ${ }^{1}$ Jonson's scholarly preoccupations culminate in Timber, or Discoveries, an elaborate commonplace book first published posthumously in $1640 . .^{2}$ In this work Jonson lays down diverse observations on the manners, morals, education, and language of his contemporaries. In the last third of Timber the author argues that effective locution reflects the very essence of humanity: 'language most shows a man, speak that I may see thee ... No glass renders a man's form, or likeness, so true as his speech. Nay, it is likened to a man; and as we consider feature and composition in a man; so words in Language.' ${ }^{3}$ According to Jonson verbal cultivation requires ordered, coherent, and eloquent delivery: 'we must take care that our words and sense be clear ... Order helps much to perspicuity, as Confusion hurts ... Whatsoever loseth the grace, and clearness, converts into a Riddle; the obscurity is marked, but not the value. ${ }^{4}$ Lack of perspicuity not only diminishes our ability to communicate, but altogether devalues our speech, as 'obscurity is marked, but not the value'.

Hristomir A. Stanev (hristomir.stanev@louisville.edu) is an assistant professor in the department of English at the University of Louisville, KY, USA. 
Jonson's lifelong obsession with the cultivation of proper expression, however, oddly disappears within his great comedies which focus on corrupting speech and on damaging aural reception. The accumulation of much verbal folly in Epicene, staged at the end of 1609, and in Bartholomew Fair, performed in the autumn of 1614, evokes, as Heather Easterling suggests, a 'radical doubt about language and an existential expression of human life and significance ... [Jonson's] suggestion that language's meaningfulness extends only so far as the rules of a game ... [becomes] a problematic conclusion for the author of The Grammar, or of Discoveries. ${ }^{5}$ In the prime of his dramatic career Jonson's fondness of eloquent expression gives way to an amusing, but essentially 'vaporous' array of natter. We wonder if such verbal chaos can be meaningful at all since it is not only confusing, but also excessively loud. In addition, what does Jonson seem to suggest about the accuracy of hearing if he dramatizes chiefly the excessive pitch and cacophony of what his dramatic prodigies blurt out?

Even though the plays do not opt for coherence, clarity, or lower decibels, they nevertheless vigorously attempt to sound out the imagined social and topographical margins of early Jacobean London. I am hardly the first to observe that Bartholomew Fair and Epicene render an acoustic panorama of the city through fashionable, often idiosyncratic language that veers into a nonsensical dramatization of the rapidly shifting socio-economic fabric of the metropolitan terrain. Earlier work by Karen Newman, ${ }^{6}$ as well as Easterling's monograph on the relationship between Renaissance city comedies and urban diction, treat the plays as lexicons that 'stag[e] ... the relationship between the vernacular and the city ... [exploring] the adequacy of language or discourse to create or sustain legitimate social coherence when it becomes fashion or commodity only' ${ }^{7}$ Both critics suggest that the highly pitched chatter in each play legitimizes a privilege of entering into peculiar modes of city talk and socializing, which in turn reflect the greater social freedoms of Jacobean Londoners, particularly of women. Mimi Yiu and Carol Lise Hayes further discuss Epicene as an audible testimony of the intricate mapping of London's gendered topography. ${ }^{8}$ According to Yiu women's chatter in the play necessarily alters the meanings of domestic comfort and affects patriarchal authority in the family (Rebecca Merrens has also suggested this point ${ }^{9}$ ). Analyzing Bartholomew Fair, Eric Wilson brings attention to the highly discordant soundings of another early modern urban phenomenon, the dynamic marketplace. He reads the high distortion of sound as a potential reflection of 'the complex conditions of [London's] contemporary 
economic soundscape, convert[ed] to the capital of theatrical alchemy by testing a variety of social interactions and speech situations throughout the course of the play'. ${ }^{10}$ More recently, Newman's continued study of Epicene has attempted to probe more deeply into the relationship between early modern sensory experience and Jonson's drama. ${ }^{11}$ Regarding acoustic distortion, Newman, like Wilson, relates the play's abrasive soundscapes to the increasingly more complex socio-economic dynamism of Jacobean London.

I agree with Newman, Easterling, and Wilson that city talk in each play, in intimating at a state of sonic anarchy, potentially reflects the arbitrary manner of encoding and decoding language on the streets and in the private quarters of Jacobean Londoners. I wish to suggest, however, that we may profit further by reading Jonson's loaded sonic environments as peculiar studies in the early modern reception of speech and heard meanings. The plays, I argue, examine the increasingly more troublesome and alienating nature of heard meanings and the diminished value of communication in Jonson's contemporary urban milieu with a deeper concern than commentators have usually allowed. While critics have chiefly focused on the social and commercial forces responsible for generating the noise and arbitrary speech forms in Jonson's drama, I wish to study the sense of sonic alienation woven within the fabric of each play and triggered by the delivery of voiced words and sounds that often fail to register as productive and meaningful. I read both works as centrally concerned with the phenomena of noise ${ }^{12}$ and aural loss in speech, and hope to demonstrate that among other objectives, Jonson's plays were meant specifically to delve into the wounded register of hearing within the challenging soundscapes of Jacobean London.

How did Jonson and his audiences understand the difference between 'speech' and 'noise' and how did they imagine successful verbal communications? In answering those questions we should be aware, as Bruce Smith argues, that if soundscapes involve constant interaction between speech communities and their acoustic environment, then we must expect to find in the culture of early modern England fundamental differences from our own culture not only in the range of available sounds but in the degree and quality of the interchanges'. ${ }^{13}$ Moreover, distinguishing 'noise' from 'speech' is problematic because, as Michel Loeb explains, the former usually connotes one of three possibilities: 'a sound varying randomly and aperiodically in intensity and frequency ... a sound which interferes with the reception of another ... [and] finally, a sound which we do not want to hear'. ${ }^{14}$ All three categories appear in Bartholomew Fair and Epicene where the characters 
identify interfering speech, as well as unwanted words, as 'noise'. 15 The perception of noise could hence figure as purely subjective rather than as shared in common. In addition, as Penelope Gouk reminds us, 'English ideas of hearing in the seventeenth century drew extensively on classical and recent continental sources', ${ }^{16}$ and neither in Latin, nor in Greek, nor in Arabic texts of the antiquity and middle ages, does 'noise' connote a type of undifferentiated, uniform sound. ${ }^{17}$ When mentioned in such writings, 'noise' occupies a distinct pitch register and usually relates to the sounds of nature or to the sounds of human interaction, such as the 'noise of a crowded assembly' ${ }^{18}$ Crowded assemblies, however, certainly could and did voice patterned speech. ${ }^{19}$ It would follow that speech could be at times a type of noise. In such cases the rationale behind qualifying certain types of speech as noise would rather be dictated by hearing words as noise as opposed to speaking words as noise. Jonson reached the same conclusion in Timber by remarking that 'if the obscurity happen[s] through the hearer's or reader's want of understanding, I am not to answer for them, no more than for their not listening or marking; I must neither find them ears nor mind'. ${ }^{20}$ The difference between 'noise' and 'speech' for Jonson and his contemporaries was often understood as a difference in auditory reception, particularly when certain noises were, in fact, spoken words.

To be meaningful, articulated sounds would hence need to avoid qualification as 'noise', but did Jonson specify when speech would be particularly effective? Timber tells us that 'juice in language is somewhat less than blood; for if the words be but becoming and signifying, and the sense gentle, there is juice; but where that wanteth, the language is thin, flagging, poor, starved, scarce covering the bone. ${ }^{21}$ Jonson's remarks reveal further that words are 'becoming and signifying' particularly when one applies 'plain and pleasing' language, rejects neologisms and extended metaphors, and considers carefully 'the persons we make speak, or the things we speak of'. ${ }^{22}$ Exploring the problem of effective communication three centuries after Jonson, J.L. Austin argued that appropriate patterns of speech ordinarily presuppose two 'procedures of linguistic legislation', ${ }^{23}$ name-giving and sense-giving, which develop in relationship to the manner in which we connect them to four performative speech acts: placing, stating, instancing, and casting (identifying). ${ }^{24}$ Performative speech acts fail when challenged respectively by instances of miscalling, misdescribing, misexemplifying, or misidentifying. ${ }^{25}$ Austin's and Jonson's categories of verbal error engage similar concepts despite their different nomenclature. What Jonson calls 'plain' (ordinary and direct) 
language would reduce the risk of what Austin terms 'misdescribing' and 'misidentifying'. Cant and florid speech would easily breach the effectiveness of communication in Jonsonian terms (and increase the risk of 'misexemplifying' in Austin's terms), while measured and common words would likely succeed in reaching listeners.

If 'noise' resides in hearing rather than in the act of articulation, Renaissance dramatic scenes that focus chiefly upon acoustic reception might reveal considerable aural discomfort. In addition, Jonson's insistence on the voicing of 'plain and pleasing' words suggests that onstage communication that comprises excessive jargon and 'professional' or 'peculiar' language further adds to a sense of sonic confusion. A systematic exploration of the two plays under these terms also unravels an impressive array of already altered domestic, sexual, occupational, and class-based hierarchies that additionally challenge conversation. In Bartholomew Fair the intensity and accumulation of region-specific and 'professional' dialects and cants evoke both misrule and heterogeneity, ${ }^{26}$ while in Epicene language often complements an ostentatious display of sexual ambiguity to achieve a scandalous degree of impropriety. When failed hearing and confusing speech join with the oddities of the assembled dramatic cast, a degree of social alienation emerges unfamiliar to us from Jonson's earlier works. Epicene, for instance, not only stretches talk to bend gender and to accommodate the rhetorical 'authority' of hermaphrodites, but often challenges conversation by representing actually how little speakers and hearers have in common. A domineering aristocratic wife and a subservient blue-collar husband, or a lover of noise and a lover of silence pair up uneasily for a chat that usually results in 'absurd, absurd, absurd' (5.3.181). ${ }^{27}$ Beyond exploiting the comic possibilities of staging such antipodes, the disparity and sheer crescendo of 'odd' voices in Jonson's works materialize the acoustic fabric of urban heterogeneity, in which the absence of sufficiently 'plain' patterns of speech separates urban dwellers from one another and fractures their already highly theatrical identities onstage.

In all likelihood, linguistic variety was a prominent feature of the London speech communities in the early years of James I's reign when inhabitants of the capital 'heard much variation in the speech of their fellow citizens'. ${ }^{28}$ Although the two 'native' dialects of the city, 'London English' and the incomplete 'Standard English', were not as different from each other as they are today, the recorded evidence of foreign accents reveals that English as a second language was used daily. The Bridewell Court Records, for instance, provide evidence that criminals and prostitutes interacted often with foreign 
visitors and diplomats. ${ }^{29}$ Additionally, 'the indigenous Celtic languages were more widely spoken during the early modern period than nowadays ... Scottish Gaelic, Irish Gaelic, and Welsh, Cornish, and Manx were still living languages, and visitors from those parts would have brought their speech to London with them. ${ }^{30}$ The monarch himself did not speak the 'London' dialect, but was influenced by his Scottish upbringing. His most important prose work, the Basilicon Doron (1599), was 'successfully "Englished" over the several editions that followed his initial manuscript edition in Scots, but the king's prose and speech remained "everywhere thickly strewn ... with images and phrases ... full of pawky Scottish humor". 31

In the second decade of the twenty-first century we can hardly imagine the spoken forms of 'metropolitan' language as anything other than a bevy of varied accents, diverse methods of articulation, and, frequently, as foreign talk that shares little common vocabulary. The London of Ben Jonson, on the other hand, had only recently begun to expand rapidly ${ }^{32}$ and could not be seen yet as a massive cosmopolitan community, thriving on the very notions of articulated difference and variety which we accept today as the quintessence of larger cities. Jacobean London's linguistic diversity becomes richer when we take into further account the rapid blooming of sub-community idiolects, such as thieving cant, as well as the alien speech of foreign migrants. The latter become a source of considerable interest and amusement in Thomas Dekker's civic romance The Shoemaker's Holiday (1599), ${ }^{33}$ as well as in John Marston's satirical comedy The Dutch Courtesan (1605), ${ }^{34}$ dramatizing the xenophobic prejudice of glib and excessive native talkers who affectedly adopt the chatter of foreigners. Such instances reveal that Londoners responded to unfamiliar and idiosyncratic visitors by borrowing their vocabulary on certain occasions. They also show that the more garbled or unclear speech patterns Jonson's contemporaries used could begin to reconceptualize social space in the city and redefine its margins and meanings. Clarity of expression became increasingly more problematic when the canters, foreigners, those with regional accents, and those with 'London' accents crossed paths on a daily basis in the city markets, parks, streets, taverns, and playhouses. Loudness, on the other hand, both in speech and inarticulate sound, increased exponentially.

A visitor to early Jacobean London would be impressed not only with the size of the city, but also with the booming sonic texture of the urban landscape. Smith enlists several testimonies of foreigners like the German jurist Paul Hentzner, who, while visiting the city in 1598, observed that 
the 'English [we]re vastly fond of great noises that fill the ear, such as the firing of canon, drums, and the ringing of bells, so that it is common for a number of them ... to go up into some belfry, and ring the bells for hours together for the sake of exercise. ${ }^{35}$ Jonson's one-time dramatic antagonist and collaborator, also an accomplished pamphleteer and urban chronicler, Thomas Dekker, could not agree more. In The Seven Deadly Sins of London (1606), Dekker's narrator depicts the streets and buildings of public recreation as excessively loud. The cacophony of urban life persecutes him everywhere 'for ... carts and coaches make such a thundering as if the world ran upon wheels ... besides, hammers are beating in one place, tube hooping in another, pots clinking in a third'. ${ }^{36}$ Visiting the Bear Gardens, Dekker's narrator complains further that 'no sooner was [he] entered but the very noise of the place put [him] in mind of Hell ... all the air was filled with noise, as if Heaven had been angry.37

In these same writings, the thunder of cannons, the clangor of bells, the sounds of traffic and artisanal work, and the roaring of animals and spectators in the Bear Gardens are matched by the equally challenging cacophony of spoken words. In the absence of industrial polluters, which would almost completely drown the noise of street conversations, the sounds of human interaction were naturally among the louder perceptible noises in the urban terrain. ${ }^{38}$ As Smith suggests, 'the sound of people talking — not just hawking their wares or clearing a passage for someone important - but talking, would, to us, be the strangest feature of the urban soundscape of early modern London'. ${ }^{39}$ Dekker's pamphlets reveal that loud verbal articulation in the city displeased the author as much as the vexing noise of human labour and transportation. In The Dead Term (1608), the personified city of Westminster remarks that 'in the open streets is such walking, such talking, such running, such riding, such clapping too of windows, such rapping at chamber doors, such crying out for drink ... and such calling upon shots, that at every such time, I verily believe I dwell in a town of war. ${ }^{40}$ Smith observes further that 'what Dekker's catalog [of sounds in this passage] suggests is not a drone of broad-band sound, but a scatter of jingles, bangs, crutches, clops - and voiced words... In the absence of ambient sounds of more than $70 \mathrm{~dB}$ (barking dogs excepted), the sound of outdoor conversations would become a major factor in the sonic environment. ${ }^{41}$ For Dekker in 1608 such sounds have already become a source of inconvenience and distraction. Moreover, The Dead Term reveals that loud talk was not only annoying, but also represented linguistic adulteration that challenged acoustic reception 
and decreased the value of communication: 'when I hear such trampling up and down, such spitting, such talking, and such humming, every man's lips making a noise, yet not a word to be understood, I verily believe that I am the Tower of Babel newly to be built up, but presently despair of ever being finished, because there is in me such a confusion of languages'. ${ }^{42}$

Comparing the London 'tongues' to the linguistic mismatch associated with the Tower of Babel, Dekker brings attention to the combined effects of loud articulation and idiosyncratic patterns of speech, which result in 'making noise, yet not a word to be understood' and collectively degrade language to the level of 'confusion', subjecting the form and value of conversation to the laws governing acoustic pollution. In this context Jonson's concern with aural loss and the ordeals of hearing stemming from loud, but rather nonsensical communication, not only seems topical but poised to expose a major challenge in the urban environment that bars access to one of the most essential elements of learning: proper understanding of the laws that govern and legitimize forms of social coherence. Jonson's humanistic concern appears to have been augmented, though, by his eagerness to explore the problem through the medium of stagecraft. Deprived of capacity to hear properly, his dramatic inventions become 'prodigies', whose attractive aural 'deformities' nevertheless comprise a major breach of the decorum of an age centrally impacted by humanist pedagogies.

As D.R. Woolf reveals, a number of significant documents compiled in the years of Elizabeth I and her successor James begin important didactic passages with the phrase 'you have heard'. ${ }^{43}$ Thomas Danett's A Continuation of the History of France (1600), William Camden's Britain (1610), and John Speed's The History of Great Britain (1623), for instance, introduce relevant bits of information by referring to the audible characteristics of the written text, in which an audience has undoubtedly 'heard' of the events that will be presented. Camden, who was also Jonson's instructor, was particularly strict in urging his readers to 'hear the very words out of that private history' ${ }^{4} 4$ in justifying a quotation in his text. Midway through his account of the deeds of King Edward III, John Speed pauses to remind his readers of what has been described before and to introduce the subsequent section of his work: 'You have heard a part of great king Edward's victorious fortunes in battle, both by land and sea; be not ignorant of his piety. ${ }^{45}$ Such attention to the aural, rather than written nature of texts, seems somewhat unexpected at the bloom of the English Renaissance, which, according to Lucien Febvre ${ }^{46}$ and Walter Ong, ${ }^{47}$ was a period of transition from 'the age of the ear' to 'the age 
of the eye', marking a 'shift towards the visual throughout the whole cognitive field'. 48 As Gouk points out, the refutation or endorsement of Febvre's and Ong's claims is complicated by the fact that 'hearing was actually an important concern of the seventeenth-century English intellectual tradition but its significance has been obscured because it was not treated as a unified subject, nor was any book ever devoted to it'. ${ }^{49}$ 'The examples from Camden and Speed suggest that British humanists 'thought of their works not as silent artifacts to be studied exclusively with the eye, but as instruments to the conveyance of their authorial voice to a public, which was in turn conceived of as a listening audience'. ${ }^{50}$ Renaissance forms of knowledge were meant to be heard. Many seminal writings, such as Helkiah Crooke's Mikrokosmographia (1616), ${ }^{51}$ or Richard Brathwaite's Essays upon the Five Senses (1620), ${ }^{52}$ consider hearing as even more important than sight in matters of comprehension. In Sylva Sylvarum (1627) Francis Bacon, the preeminent Jacobean authority on matters of scientific and philosophical exploration, states that: 'It hath been anciently held, and observed, that the sense of hearing ... [has] most operation upon manners ... the cause is, for that the sense of hearing strikes the spirits more immediately, than the other senses ... speech must come by hearing. 53 By registering speech, hearing is considered a natural conduit to forming a repository of ideas. This relationship corresponds to Aristotle's main argument in De Sensu about the distinct role of hearing in the formation of cognition: 'from the point of view of thought ... hearing is the more important [in comparison to sight] ... has the greatest share in the development of intelligence ... of those who from birth have been without one or other of those two senses, the blind are more intelligent than deaf-mutes' 54

The Jacobean era did not essentially oppose Aristotle's perception of the cognitive capacity of hearing to stimulate learning and intellectual growth. Crooke mainly challenges Aristotle in regard to the mobile aspects of sound. He argues that 'sound can be no motion', while Bacon sets a series of Aristotelian observations on the quality and transmission of sound as hypotheses to be proved. ${ }^{55}$ Other writers of the period, such as the religious polemicist Henry Smith, also openly endorse Aristotle's doctrine. In The Art of Hearing in Two Sermons (1592), Smith argues that the degenerate character of his age is not due to a scarcity of decent teachers or teaching methods, but to 'the want of hearing'.56

A 'want' or 'lack' of proper hearing, however, could have serious repercussions upon the fortunes of a playwright. Epicene offended so much King James's cousin, Lady Arbella Stuart, through a misinterpreted remark 
concerning a fraudulent continental nobleman who had tarnished her reputation that it lead to the play's immediate censorship. ${ }^{57}$ The bitter experience must have warned Jonson of the dangers involved in the free circulation of heard meanings because the induction to Bartholomew Fair actually invites onstage a scrivener who recites a mock warrant for misperception. The warrant asks all 'spectators and hearers' $(166)^{58}$ to remain seated and to apply vigilantly their sensory organs in order to 'exercise their own judgment, and not censure by contagion, or upon trust from another's voice' (1l 87-8). Jonson, who had closely escaped the literal loss of his own ears while imprisoned for having offended King James in Eastward Ho! (1605), one of his previous collaborations with Marston and Chapman, ${ }^{59}$ may have been careful to stave off unwanted aural reception among the audiences but remained no stranger to the tacky complexity of the issue in the course of the play. Even the most erudite and learned of his dramatic cast in Bartholomew Fair, Overdo, a justice of the peace who visits the eponymous fair committed to uncovering the enormities of sin among the London crowds, suffers from dreadful auditory decoding. Compelled to express moralistic sentiments at the very heart and heat of the fair, Overdo delivers an oration against the evils of drinking and tobacco. Taken at their face value Overdo's words unleash a long list of social evils. Jonson, however, limits the function of articulation to the highly theatrical means of speech delivery. Form takes precedence over direct meanings and implied sense. When a foolish country squire called Cokes and his guardian Wasp hear Overdo's grave oration, they begin to debate whether his speech is 'brave' 60 or not, and do not offer the least interest in what it actually means:

COKEs This is a brave fellow, Numps; let's hear him.

WASP S'blood, how brave is he ...

COKEs Brave words ... are they not brave words, sister ...

WASP Heart, let 'em be brave words, as brave as they will! An they were all the brave words in a country, how then ...

COKEs That's to us, sister. Brave i' faith!

$$
(2.6 .15-16 ; 22-4 ; 27-8 ; 63)
$$

Such 'brave' articulation rapidly culminates in a senseless vocal crescendo at the end of the scene when 'they speak all together, and Wasp beats the Justice' (2.6.132), shouting: 'What can any man find out in this bawling fellow to grow here for? He is a full handful higher sin' he heard him ... Hold your 
peace, you roaring rascal ... Heart, I never knew one taken with a mouth of a peck before' (2.6.82-90). The scene not only fulfills two of Loeb's categorizations of 'noise' (as an unwanted, as well as a 'masking', sound), but also presents a fertile instance of exploring inadequate hearing rather than inadequate speech.

The 'brave' words of Overdo, however imposing and loud, would hardly fail with conviction Jonson's criteria laid in Timber about the value of speech. The judge identifies his subjects with common words ('ale', 'bottle', 'plant', 'tobacco', 'pox') and proceeds by enlisting series of examples that sometimes evoke the exotic ('alligator'), but generally retain a simplified relationship between what Austin calls the performative acts of 'placing' and 'identifying': 'And hear what malady it doth the mind. It causeth swearing, it causeth swaggering, it causeth ... snarling' (2.6.64-6). That Overdo's rather simplified rhetoric is qualified as either 'brave' or 'roaring', but in no way as meaningful, suggests that Cokes' and Wasp's hearing apparatuses malfunction. To underscore the point, Jonson reiterates the experience in the subsequent act by having Cokes listen to a mellifluous 'warning' against the bad habits and dangers of socializing in London. The song comprises the vocal efforts of a singer of new ballads called Nightingale but to Cokes's ears all amounts to a ' $F a$, la, la, la, la, la, la, fa, la, la, la' (3.5.56). The country squire fails to 'hear' a profitable lesson once again, providing instead appreciation of Nightingale's method of articulation but not an understanding of what his song means. Cokes hence has his pockets picked while listening to the ballad, which literally warns him of the practices of criminals in a 'plain and pleasing' manner: 'My masters and friends and good people draw near, / And look to your purses ... you oft have been told, / both the young and the old, / And bidden beware of the cutpurse so bold' (3.5.62-3; 68-70). Not only does the implied act of hearing ('you oft have been told') in this passage reflect the essentially didactic nature of proper auditory reception for Jonson and his contemporaries, but reinforces the playwright's skeptical and ironic assessment of the application of one's hearing organs at the fairground.

Besides studying wounded hearing in moments of erudite and clear utterances, Jonson also focuses upon mere 'nonsense', a word that he used in Bartholomew Fair and which represents only a second recorded usage according to the $O E D .{ }^{61}$ The play's nonsensical language culminates in a game of 'vapors', centered upon the vocal efforts of Cokes' guardian Wasp, and backed by a bevy of heterogeneous speakers, who blurt out as many verbal vapors as their lungs can sustain. The following excerpt may be taken as an 
illustration: 'I'll ne mare, I'll ne mare, the eale is too meeghty' complains a dizzy man called Northern, whose name and articulation intimate at his origins (4.4.3). Northern's complaint is cut short by the 'Turnbull' roarer Dan Knockem, a resourceful lover of the jargon of horse-dealers: 'How now! My Galloway nag, the staggers! Ha! Whit, gi' him a slit i' the forehead. Cheer up, man; a needle and thread, to stitch his ears. I'd cure him now, an I had it, with a little butter and garlic, long-pepper and grains' (4.4.4-7). At that moment Northern's associate, a wrestler called Puppy, interrupts Knockem's tirade in a third regional dialect: 'Why, where are you, zurs? Do you vlinch, and leave us i' the zuds now' (4.4.9-10)? Puppy's indignant remark at Northern's infirmity in turn gives way to the comical Irish accent of the pander Captain Whit: 'Who told dee sho? That he vuld never teer, Man ... He shall not pardon dee, Captain; dou shalt not be pardoned. Pre'de shweetheart do not pardon him' $(4.4 .16 ; 21-2)$. This comical bevy of inflected accents, united perhaps only by their lack of adhering to a uniform dialect gradually become preoccupied with their own incoherence and an argument ensues:

кNOCKem If he have reason, he may like it, Sir.

whIT By no meansh Captain, upon reason, he may like nothing upon reason.

WASP I have no reason, nor I will hear of no reason, nor I will look for no reason, and he is an Ass that either knows any, or looks for it from me.

CUTTING Yes, in some sense you may have reason, Sir.

WASP Aye, in some sense, I care not if I grant you.

whIT Pardon me, thou ougsht to grant him nothing, in no shensh, if thou do love dyshelfe, angry man.

WASP Why then, I do grant him nothing; and I have no sense.

CUTTING It is true, thou hast no sense indeed.

WASP S'lid, but I have sense, now I think of it better

In this passage, Jonson's festival of random and peculiar speech in which no form takes real precedence over others somewhat surprisingly gives over to self-reflection, pondering upon the lapses in communication that either do not require or cannot deliver any valid 'reason' or 'sense', even if a speaker ends up convinced that he or she 'has sense'. The clamorous game of vapours 
preceded by Overdo's lengthy orations materializes a Dekkerian Tower of Babel. The inability of Jonson's cast to bear each other's stentorian vapours is so prominent that after all else fails, they literally 'fall by the [ir] ears' (4.4.99) and attempt to use fisticuffs instead of words. When the commotion finally subsides, the play suggests that the only way to pour some sense into the defective ears of such characters is to offer some hearing aid. Justice Overdo receives a most unwelcome auditory boost, in which a witty character called Quarlous remarks: 'Sir, why do you not go on with enormity? Are you oppressed with it? I'll help you. Hark you, sir, i' your ear: your "innocent young man" you have ta'en such care of all this day, is a cutpurse that hath got all your brother Cokes his things' (5.6.71-4, my italics).

Bartholomew Fair thus targets sonic failure which alienates listeners from speakers through the invasive volume and heterogeneity of talk, as well as through the inept hearing characters possess. In so doing Jonson complements a world of class antagonism and social polarization that allude to the social conflicts which developed in early Jacobean London when the increased numbers of pocket communities and aliens collided with more mainstream metropolitan dwellers. The rapid alternation of Scots, mockIrish, and the professional jargon of pimps, thieves, and horse-dealers in this play challenges the role of 'sense' or 'reason' in acts of locution and their auditory reception. Jonson appears hesitant at best about the recovery of essential aural information in the urban terrain which is drowned by idiolect, noise, as well as by the often incompatible backgrounds of speakers, affected by class and occupation. In this sense the play builds an image of the city community in a state of auditory lapse. It makes even more sense that the only reliable bit of information in the play is never audibly spoken, but written. Where all else fails, Justice Overdo's name laid out on an empty sheet of paper and used as a universal warrant advances the fortunes of one Winwife over Cokes and remains the only adequate and irrefutable authority throughout the play. This document perhaps also reminds the 'hearers' at the Hope Theatre of their own acceptance of the Scrivener's mock-warrant in the play's induction, which, among other matters, sought to limit the frivolous application of one's potentially defective auditory organs.

Jonson's silenced offspring Epicene, on the other hand, focuses on the loss of auditory value and its strained reception within households rather than in the noisy street and fairgrounds of Jacobean London. If spectators were to cherish any hopes that in Jonson's drama domesticity may be soundproof or at least conducive to productive communication and excellent hearing, they 
might need to reconsider this stance. What Epicene delivers right away upon entering the bower of bliss of an odd couple called the Otters is the exasperated plea of a demoted husband begging for aural attention, pleading to be allowed to talk, and more importantly, to be heard: 'Nay, good princess, hear me pauca verba ... sweet princess, gi' me leave' (3.1.1; 9-10). His wife will have none of it, though: 'By my integrity, I'll send you over to the Bankside, I'll commit you to the Master of the Garden, if I hear but a syllable more' (3.1.25-7). The Otters' neighbor Morose, a sulky and unwelcoming gentleman of ample means whose most distinguishing characteristic is his hatred of noise, suffers even worse than the he-Otter. When another witty gentleman named Truewit delivers to Morose an excessive oration against the ills of women and marriage, his host's capacity to express anything collapses. Even though Truewit claims that 'the sound of [the horn] might have pierced your ears with gladness' (2.4.3-4), Morose's remarks during the oration mostly constitute monosyllabic wailing. At the end of Truewit's tirade Morose is a sick man suffering from sonic overload: 'Here has been a cutthroat with me; help me in to my bed, and give me physic' (2.2.134-5). He has hardly registered anything from the massive oration except its abrasive quality. Truewit, in turn, has effectively silenced his host through an overdose of pointless information that qualifies no worse than the blowing of the horn as excellent 'noise' of the kind Morose cannot stand.

Like Bartholomew Fair, Epicene reflects the loss of auditory reception due to alien or overly aggressive and often idiosyncratic speech or sound patterns, but appears even more concerned with measuring the tolerance threshold of one's eardrums. The railing of the she-Otter and her patrons, the Lady Collegiates, a cross-pollination, as the play explains, between 'courtiers and country madams' (1.1.69) is particularly loud and abrasive. The feminine furies incessantly 'cry down or up what they like or dislike in a brain of fashion with most masculine, or hermaphroditical, authority' (1.1.72-3), challenging not only sonic barriers, but conventional female access to speech and assertiveness, a notion figured in their indeterminate sexual characteristics. Their presence reduces pleas to be heard and understood to humiliated silence or to the strained utterance of 'Madam-' (3.6.78) at best. The aggressive voices of Truewit and the Collegiates generate hearty laughs but also set a pattern of reducing the accuracy of hearing by embodying all three of Loeb's definitions of 'noise' as sounds that 'mask' other sounds, become undesirable, and offer uncomfortable and unpredictable pitch characteristics. 
Jonson's festival of strained auditory reception culminates in the last two acts and targets a pompous duo comprising an insipid scholar, John Daw, and a vapid dandy, Sir Amorous La Foole. Daw and La Foole are unique among Jonson's cast in that they not only speak poorly but also hear tragically. At the end of the fourth act Truewit enacts a jocular revenge upon Daw and La Foole for tarnishing the reputation of Morose's nephew. The jest is thoroughly acoustic and forces Daw to hide and 'keep [his] breath close that [the supposedly enraged la Foole] does not hear [him] sigh' (4.5.77). The horrified coward cringes behind a curtain while Truewit loudly and ironically pleads to an invisible listener to hear his words and calm down: 'I never knew a man's choler so high, but he would speak to his friends, he would hear reason' (4.5.81-2). Once the 'threat' is gone Truewit brings out Daw from his hiding place and right away makes sure that the latter's hearing is as defective as his sententious poetry is vapid: 'Did you hear him?' (4.5.85). Scared beyond his wits Daw immediately confirms, which brings another ironical aside from his companion: 'What a quick ear fear has' (4.5.85). Daw has heard nothing beyond Truewit's voice, but mislead by his peculiar ability throughout the play not to hear anything that makes sense, he falls right into Truewit's trap and agrees to receive six kicks. ${ }^{62}$

Sir Amorous finds himself in the same dire straits for misinterpreting the altered voice of Truewit who 'feigns [it] as if one were present, to fright the other' (4.5.192-3) and accepts to have his nose tweaked by Dauphine while the Collegiates secretly observe the scene. The subsequent comical fumbling of Daw and La Foole at hearing each other is even more disoriented. They interrupt each other constantly, unsure whether the other has spoken and whether they should say anything:

LA FOoLE Nay, out with it, Sir John; do not envy your friend the pleasure of hearing ...

DAW Why — a - do you speak, Sir Amorous ...

LA FOole No, do you Sir John Daw ...

DAw I'faith, you shall ...

LA FOOLE I'faith you shall.

While such instances reaffirm the wounded nature of auditory reception in Epicene, Jonson further appears to invite his audiences to experience what a lapse of hearing would involve. He literally stages the effects of prolonged 
alien talk upon his dramatic cast and spectators who would have picked up probably a third or less of what the barber Cutbeard, disguised as a canon lawyer, and the he-Otter, disguised as a Puritan divine, deliver in Latin in the penultimate scene of the play. If up to now Epicene alienated speakers from listeners by damaging hearing inside the staged world of Jonsonian fantasy, the literal foreignness of unfamiliar language in the last act invades directly the ears of patrons and visitors. One may wonder, though, if such an invasion would be truly unwelcome: after all, Puritan divines and canon lawyers were expected to 'cant' extensively and their representation on stage in their 'true' element could be a source of considerable amusement. ${ }^{63}$ At first Otter indeed appears to address the unseen audience at the Hope by translating and commenting upon the barber's Latin (and, therefore, reminding audiences that he is merely impersonating a member of an often ridiculed religious faction). He gradually stops making his Latin understandable, however, and joins the 'lawyer' in inundating the acoustic space of the playhouse with cryptic phrases. The Latinate exchange is unusually long (stretches over a hundred and fifty dramatic lines) and centres upon Morose's devastated response, 'what's all this to me' (5.3.152). While amusing audiences through the familiar and perhaps expected dramatization of the 'canting' skills of a religious extremist and an irksome lawyer, Jonson's decision to eliminate translation altogether and to focus instead on Morose's 'Good sir, let me escape ... O, mine ears ... Good echoes, forbear' (5.3.200; 209; 212) also conveys the invasive and confusing character of prolonged exposure to unfamiliar diction.

Morose's plight is arguably the worst in the play and he gradually emerges as the bona fide victim of urban acoustic pollution. His inability to listen to the orations, music, railings, and cries of his visitors and neighbors not only makes him walk in socks and devise double-caulked doors and triple-caulked windows, ${ }^{64}$ but also transforms him into a peculiar urban landmark. Having no other means to dampen the invasive sonic overload in his home, Morose resorts to escape, as another character describes, 'over a cross-beam o' the roof, like him o' the saddler's horse in Fleet Street, upright; and he will sleep there' (4.1.21-3). Standing like a monument in the attic of his house, notoriously alone and alien to the noisy world that surrounds him, Morose recalls the wooden statue in one of London's busiest urban streets. In rejecting the city he simultaneously takes part of its iconic lore of material signs and figures as a cultural artifact that brings about the all-encompassing but nameless and amorphous sonic totality of the urban world. Estranged from the 
acoustic distortions his visitors deliver, Morose is unable to make meaning of the 'spitting, the coughing, the laughter, the sneezing, the farting, dancing, noise of the music' (4.1.7-8), and the chatter that collectively distort the soundscapes of urban society. His pseudo-martyrdom ultimately suggests the alienating effect of the anarchistic sounds of a crowded urban setting. For Morose the noise of London is incomprehensible and unfamiliar, offering no valuable interactions and no valuable language ('what's all this to me'). He admits that in such a universe the only speech that he tolerates and enjoys is his own discourse. Instead of fulfilling Jonson's cherished vision of speech as a humanizing and ennobling ideal, Morose's deformed and auto-fulfilling locution, as well as hearing malaise, reduce him to a simulacrum of a monument, a solitary form of nonsense amidst the eloquent, though abrasive and often alienating polyvocality of his visitors from the city.

If we analyze the strained reception of heard meanings onstage through moments of defective speaking and defective hearing (or a combination of both, such as the shaming of Daw and La Foole), we notice that Jonson's two comedies lodge effective critiques of Jacobean forms of social communication. On the surface, each work celebrates the sea of voiced city sounds that include the loud chatter of guests, the noises of artisanal work and protoindustries, the greater access of women to forms of self-expression, as well as the diverse and often confusing forms of patterned speech, which blend voice, song, ringing, shouting, and a variety of dialects and 'professional' accents. Such soundings create a sonic carnival that takes the form of numerous 'vaporous' games, pranks, and deliberate investment in the art of noisemaking, but we should not forget that Jonson's prefaces to his plays invariably stress a deeper goal: to 'mix profit with pleasure' (Volpone, Prologue 8). 65 'The 'profit' of following the rough music of the London soundscapes could hardly be the sole cultivation of aural crescendo, especially in light of Jonson's convictions in Timber of the immense import of unadorned, though articulate, expression. If language in Jonson's cherished humanist projects 'most shows a man', 66 it literally least shows 'a man' in his mature comedies, displacing humanness with a bevy of 'prodigious creature[s]' (Epicene 5.4.43). In this sense, Jonson's comedies rather engage the decibels of urban dynamism to channel a sense of sonic alienation that fractures characters onstage, resulting in displaced and dehumanized ('prodigious') identities. At the end of Bartholomew Fair the only possessors of any credible acoustic authority are a cast of sexless wooden puppets performing a riotous and bawdy pageant, ${ }^{67}$ while in Epicene the tortured Morose ends up petrified like a monument 
in his own attic and in a moment of anguish in the last scene of the play attempts to convince his peers that '[he is] no man' (5.4.39).

In sounding out the city and its diverse speech situations Jonson's works further extend the symbolic domain of the warrant issued mockingly in the induction to Bartholomew Fair to police the acoustic distortion of theaters. To hear fully and comprehend better the challenges and changes of metropolitan living one needs to be a '[hu]man' rather than a sexless puppet or a 'prodigious creature', and to do so one needs to 'speak, so that [all] may see [him or her]. ${ }^{68}$ It would appear that the sounds of early seventeenth-century London offered little of immediate value to the distillation of social and human excellence; this notion perhaps did factor more than scholars have realized in Jonson's lifelong unease with and even rejection of the 'loathed' stage $^{69}$ and its voiced opinions. Jonson should have altered 'speak that I may see thee' with 'write that I may hear thee', because as the conclusions of both his plays illustrate, ${ }^{70}$ the only valuable words appear to be those attached to a piece of paper, rather than to the often defective ears of his contemporaries.

\section{Notes}

1 R.V. Young, 'Ben Jonson and Learning', Richard Harp and Stanley Stewart (eds), The Cambridge Companion to Ben Jonson (London and New York, 2000), 43, DOI: http://dx.doi.org/10.1017/CCOL0521641136.004.

2 Ben Jonson, Timber, or Discoveries Made upon Men and Matter, ed. Felix E. Schelling (Boston, 1892).

3 Ibid, 64.

4 Ibid, 63.

5 Heather Easterling, Parsing the City: Jonson, Middleton, Dekker, and City Comedy's London as Language (New York and London, 2007), 112.

6 Karen Newman, 'City Talk: Women and Commodification in Jonson's Epicoene', English Literary History 56.3 (1989), 503-18, DOI: http://dx.doi.org/10.2307/2873195.

7 Easterling, Parsing the City, 47-9.

8 Mimi Yiu, 'Sounding the Space between Men: Choric and Choral Cities in Ben Jonson's Epicoene; or, The Silent Woman', Publications of the Modern Language Association of America 122.1 (2007), 72-88, DOI: http://dx.doi.org/10.1632/ pmla.2007.122.1.72; Carol Lise Hayes, 'Mapping City Comedy: Topographies of London and the Anomalous Woman, 1599-1625', PhD thesis (University of California at Irvine, 2000). 
9 Rebecca Merrens, "'Ignoring the Men:” Female Speech and Male Anxiety in Cavendish's The Female Academy and Jonson's Epicoene', Essays and Studies in Literary Criticism 9.1-2 (2000), 243-60.

10 Eric Wilson, 'Plagues, Fairs, and Street Cries: Sounding out Society and Space in Early Modern London', Modern Language Studies 25.3 (1995), 27, DOI: http://dx.doi .org/10.2307/3195370.

11 Karen Newman, Cultural Capitals: Early Modern London and Paris (Princeton, 2007), 76-92.

12 Consider Emily Cockayne, 'Cacophony, or Vile Scrapers on Vile Instruments: Bad Music in Early Modern English Towns', Urban History 29.1 (2002), 35-47, DOI: http://dx.doi.org/10.1017/S0963926802001049. According to Cockayne, in the Renaissance 'the word "noise" connoted a variety of imprecise and often contradictory meanings ... [it was used] to describe sounds that were musical or unmusical, pleasant or unpleasant, and could also be applied to quarrelling, strife or the spreading of Rumours' (36). The Oxford English Dictionary (OED) specifies that the primary meaning of 'noise' is indeed 'sound; the aggregate of sounds occurring in a particular place or at a particular time; (also) disturbance caused by sounds, discordancy, (in early use) esp. disturbance made by voices; shouting, outcry' (1a, my italics). In Epicene and Bartholomew Fair 'noise' refers to arbitrary sounds and evades a fixed definition, but tends to be associated mostly with 'disturbance made by voices', regardless of subject, character, or occasion.

13 Bruce Smith, The Acoustic World of Early Modern England: Attending to the O-Factor (Chicago, 1999), 51.

14 Michel Loeb, Noise and Human Efficiency (Chichester and Toronto, 1986), 7.

15 Silencing Justice Adam Overdo's pulpit rhetoric in Bartholomew Fair (2.6.82-91), as well as Mute's 'making [of] a leg' instead of talking in order to please his master Morose in Epicene (2.5.3), qualify unwanted speech as noise, while the simultaneous chatter in Bartholomew Fair when 'they speak all together' (2.6.132), and as a result Humphrey Wasp beats Justice Overdo, is an instance of interfering speech treated as noise.

16 Penelope Gouk, 'Some English Theories of Hearing in the Seventeenth Century: Before and after Descartes', Charles Burnett, Michael Fend, and Penelope Gouk (eds), The Second Sense: Studies in Hearing and Musical Judgment from Antiquity to the Seventeenth Century (London, 1991), 95.

17 Charles Burnett, 'Sound and Its Perception in the Middle Ages', Burnett, Fend, and Gouk (eds), The Second Sense, 46.

18 Ibid, 46-7. 
19 Even in Shakespeare's Coriolanus (1607-8), ed. Jonathan Crewe (New York, 1999), a play famously opposed to crowds, Caius Martius recognizes that 'the rabble [i.e. the populace] ... will in time ... throw forth greater themes' (1.1.216-18) and hence voice coherently articulated ideas.

20 Jonson, Timber, 62-3.

21 Ibid, 65-6

22 Ibid, 60.

23 J.L. Austin, Philosophical Papers, eds J. Urmson and G. Warnock (Oxford, 1961), 183.

24 Ibid, 190.

25 Ibid, 191-2.

26 The erudite talk of Justice Overdo in the play is drowned by the suburban village dialect used by his foolish brother-in-law Cokes (who hails from Harrow on the Hill), the mock-Irish of a pander called Captain Whit, the Scottish inflection of the wrestler Puppy and his associate Northern, the detonations of 'Banbury' zeal spoken by the Puritan Rabbi Busy, the horse-dealer's slang of Dan Knockem, and the bawdy argot exchanged by the 'pig-woman' Ursula and her confederates.

27 Ben Jonson, Epicene, or the Silent Woman, Gordon Campbell (ed.), The Alchemist and Other Plays (Oxford and New York, 1995), 119-211.

28 Laura Wright, 'Speaking and Listening in Early Modern London', Alexander Cowan and Jill Steward (eds), The City and the Senses: Urban Culture since 1500 (Aldershot, UK and Burlington, VT, 2007), 72.

29 For specific Elizabethan entries from the Minutes of the Court of Governors of Bridewell and Bethlem, consider Wright's useful compilation in 'Speaking and Listening', 62-3.

30 Ibid, 63.

31 Quoted in Easterling, Parsing the City, 33.

32 Consider Derek Keene, 'Material London in Time and Space', Lena Cowen Orlin (ed.), Material London, ca. 1600 (Philadelphia, 2000), 55-75. According to Keene (58), the main catalyst of change was steady immigration, which the continuous impoverishment of the countryside provoked. Life had become particularly challenging when a period of economic hardships, plague epidemics, grain crises, and pervasive famine hit the British Isles. Subsistence migration of the economically weak, seeking marginable employment or some form of charitable relief, made a substantial contribution to the growth of London's population at the end of Elizabeth's reign. 
33 Thomas Dekker, The Shoemaker's Holiday, eds R.L. Smallwood and Stanley Wells (Manchester, New York, and Vancouver, 1999). In Dekker's play the journeyman Firk mocks the Dutch accent of the disguised aristocrat Rowland Lacy.

34 John Marston, The Dutch Courtesan, ed. Martin Wine (Lincoln, 1965). Marston's city trickster Cocledemoy successfully impersonates a French peddler and a Scottish barber.

35 Smith, The Acoustic World of Early Modern England, 53.

36 Thomas Dekker, The Seven Deadly Sins of London (London, 1606; sTC 6522, ESTC S105270), 26.

37 Ibid, 37-8.

38 For a detailed comparative chart of human and industrial noise, including the probable register that early modern Londoners encountered, consider Figure 3.1 in Smith, The Acoustic World of Early Modern England, 50.

39 Ibid, 58.

40 Thomas Dekker, The Dead Term (1608), Alexander B. Grosart (ed.) The Non-Dramatic Works of Thomas Dekker in Five Volumes (London, 1885), 4.25.

41 Smith, The Acoustic World of Early Modern England, 58.

42 Dekker, The Dead Term, 51.

43 D.R. Woolf, 'Hearing Renaissance England', Mark. M. Smith (ed.), Hearing History: A Reader (Athens and London, 2004), 112.

44 Ibid.

45 Ibid.

46 Lucien Febvre, The Problem of Unbelief in the Sixteenth Century, the Religion of Rabelais, trans. Beatrice Gottlieb (Cambridge, 1982).

47 Walter J. Ong, Ramus: Method, and the Decay of Dialogue (Cambridge, 1958).

48 Ibid, 281.

49 Gouk, 'Some English Theories of Hearing in the Seventeenth Century', 95.

50 Woolf, 'Hearing Renaissance England', 112.

51 In Mikrokosmographia (London, 1616; sтc 6062.2, EsTC S4592), Crooke claims that 'we learn things through the hearing more easily than through the sight, because the voice affects us more by inflection and insinuating itself into the sense' (quoted in Gouk, 100).

52 Richard Brathwaite, Essays upon the Five Senses (London, 1620, rpt London, 1815). Brathwaite begins his second section in the following manner: 'Hearing is the organ of understanding; by it we conceive, by the memory we conserve, and by our judgment we revolve' (9).

53 Francis Bacon, Sylva Sylvarum (London, 1627; stc 1168, ESTC S106909), 38; 65.

54 Aristotle, De Sensu, trans. G.R.T. Ross (New York, 1973), 45-6. 
55 Gouk, 'Some English Theories of Hearing in the Seventeenth Century', 98-9.

56 Quoted in Woolf, 'Hearing Renaissance England,' 120.

57 Richard Dutton, 'Introduction to Epicene, or the Silent Woman', by Ben Jonson (Manchester, 2003), 72.

58 Ben Jonson, Bartholomew Fair, Campbell (ed.), The Alchemist and Other Plays, 328433.

59 For more information on the perils that Jonson and his colleagues suffered, consider C.H. Herford Percy and Evelyn Simpson (eds), Ben Jonson, 11 vols (Oxford, 1925-52), 1.143.

60 In other words, 'worthy, excellent, good', as OED specifies ('brave' 3a).

61 The first recorded usage of the word is by A. Stafford: 'Others again, by an unwitty application, make non-Sense; and infuse loathing into the nice stomach of the Reader. I will apply nothing, which may not imply something' ('Nonsense' 1a). Jonson's play was written and staged about two years later.

62 Jonson illustrates Daw's talents to reject written or spoken authority in 2.3.40-80 when he refutes respected classical authors. Daw harkens after the 'voice' of Syntagma Juris Civilis, Corpus Juris Civilis, and the King of Spain's Bible, the first of which has never been identified, and the last of which could hardly be accepted positively by an overwhelmingly Protestant audience with recent memories of Guy Fawkes and his failed plot.

63 Consider Jonson's The Alchemist, Campbell (ed.), The Alchemist and Other Plays, 211-327, in which the playwright satirizes the canting practices of exiled brethren by having an Anabaptist duo exchange 'disciplinary' jargon with the disguised conman Subtle in 2.5. In Eastward Ho!, James Knowles and Eugene Giddens (eds), The Roaring Girl and Other City Comedies (Oxford, 2001), 67-140, similarly to Epicene, Jonson and his collaborators Chapman and Marston presented legal discourse as a fairly obscure verbal porridge by having the lawyer Master Bramble (his name meaning a thorny shrub and suggesting legal entanglement) often resort to Latin in explicating situations and legal provisions in the last act of the play.

64 As Clerimont gleefully shares with Truewit in the beginning of the play, the noisehater Morose has 'devise[d] a room with double walls and treble ceilings, the windows close shut and caulked, and there he lives by candlelight. He turned away a man last week for having a pair of new shoes that creaked. And this fellow waits on him now in tennis-court socks' (1.1.167-71).

65 Ben Jonson, Volpone, or the Fox, Campbell (ed.), The Alchemist and Other Plays, 3-117.

66 Jonson, Timber, 64. 
67 The finale of Bartholomew Fair has the dramatic cast gathered under a tent to observe a puppet play staged by one Lantern Leatherhead, a hobby-horse seller. The obscene and noisy pageant silences even the thunderous zeal of the Puritan Busy whose orations have previously rattled the fairground.

68 Jonson, Timber, 64.

69 Consider Jonas Barish, The Antitheatrical Prejudice (Berkeley and Los Angeles, 1981), 132- 55. Jonson himself used the term 'loathed stage' in the bitterly selfvalidating poem 'Ode (to Himself)'.

70 The words 'Adam Overdo' laid out neatly on a piece of paper become the only irrefutable warrant in Bartholomew Fair, while Morose's signature is the sole evidence of success and improvement in Epicene, as it advances the fortunes of his nephew Dauphine. 
